\title{
Peran Badan Pendapatan Daerah Kabupaten Kutai Kartanegara Dalam Meningkatkan Pendapatan Asli Daerah Bersumber Dari Pajak Sarang Burung Walet (Di Tinjau Dari Peraturan Daerah Kabupaten Kutai Kartanegara Nomor 2 Tahun 2011 Tentang Pajak Daerah)
}

\author{
Megawati Hairuni dan Wahyuni Safitri \\ Mega_wati96@yahoo.com ,wahyunibun@gmail.com \\ Alumni dan Dosen Fakultas Hukum \\ Universitas Widya Gama Mahakam Samarinda
}

\begin{abstract}
ABSTRAK
Kabupaten Kutai Kartanegara sebagai daerah otonom telah memiliki dokumen perencanaan pembangunan daerah sebagai satu kesatuan yang tidak terpisahkan dari sistem perencanaan pembangunan Provinsi dan Nasional. Semakin besarnya peranan Pendapatan Asli Daerah (PAD) berarti semakin sedikit ketergantungan daerah terhadap bantuan pusat. Tujuan dari penelitian ini adalah mengetahui peran Badan Pendapatan Daerah Kabupaten Kutai Kartanegara dalam melakukan penyelenggaraan pungutan dan melaksanakan pengawasan terhadap pemilik sarang burung walet dalam melaksanakan kewenangannya membayar pajak untuk meningkatkan pendapatan asli daerah dan Mengetahui perhitungan tarif pajak sarang burung walet yang ditetapkan sebesar $10 \%$ berdasarkan Peraturan Daerah Kabupaten Kutai Kartanegara Nomor 2 Tahun 2011 tentang Pajak Daerah. Metode yang digunakan dalam penelitian ini adalah normatif dengan informan utama yaitu Badan Pendapatan Daerah kabupaten Kutai Kartanegara. Hasil penelitian menunjukkan bahwa Badan Pendapatan Daerah Kabupaten Kutai Kartanegara dalam penyelenggaraan pungutan dan melaksanakan pengawasan terhadap pemilik sarang burung walet dalam melaksanakan kewenangannya membayar pajak untuk meningkatkan pendapatan asli daerah masih belum maksimal. Seharusnya dalam penyelenggaraan pungutan juga harus dilakukan pengawasan, agar dapat mengevaluasi penyelenggaraan pungutan. Perhitungan tarif pajak sarang burung walet yang di tetapkan sebesar 10\% berdasarkan Peraturan Daerah Kabupaten Kutai Kartanegara Nomor 2 Tahun 2011 tentang Pajak Daerah sudah cukup baik namun dalam segi penerapan harus dilakukan sosialisasi kepada pengusaha sarang burung walet.
\end{abstract}

Kata Kunci: Peningkatan Pendapatan Asli Daerah Bersumber dari Pajak Sarang Burung Walet. 


\begin{abstract}
Kutai Kartanegara Regency as an autonomous region has regional development planning documents as an integral part of the provincial and national development planning systems. The greater role of Regional Original Revenue (PAD) means less regional dependence on central assistance. The purpose of this study was to determine the role of the Regional Revenue Agency of Kutai Kartanegara Regency in carrying out levies and carry out supervision of swallow nest owners in exercising their authority to pay taxes to increase local revenues and to determine the calculation of the swallow's nest tax rate which was set at $10 \%$ based on the Regulation Regency of Kutai Kartanegara Number 2 Year 2011 regarding Regional Tax. The method used in this study is normative with the main informant namely the Regional Revenue Agency of Kutai Kartanegara Regency. The results showed that the Regional Revenue Agency of Kutai Kartanegara Regency in carrying out levies and carrying out supervision of swallow bird nest owners in carrying out their authority to pay taxes to increase local revenue is still not optimal. Supervision should also be carried out in the implementation of levies, in order to evaluate the administration of levies. The calculation of the tax rate for swallow's nest which is set at $10 \%$ based on the Kutai Kartanegara Regency Local Regulation Number 2 of 2011 concerning Regional Taxes is good enough but in terms of implementation it must be carried out to the entrepreneur of swallow's nest.
\end{abstract}

Keywords : Increase of Original Regional Income Sourced from Swallow's Nest Tax.

\title{
PENDAHULUAN
}

\section{A. Latar Belakang}

Mengacu Peraturan Pemerintah (PP) Nomor 8 Tahun 2008 tentang Tahapan, Tata Cara Penyusunan, Pengendalian dan Evaluasi Pelaksanaan Rencana Pembangunan Daerah sebagai derivasi dari Undang-undang Nomor 25 Tahun 2004 tentang Sistem Perencanaan Pembangunan Nasional; perencanaan pembangunan daerah merupakan satu kesatuan dalam sistem perencanaan pembangunan nasional. Hal tersebut dilakukan pemerintah daerah bersama para pemangku kepentingan berdasarkan peran dan kewenangan masing-masing, berdasarkan kondisi dan potensi yang dimiliki masing-masing daerah, sesuai dinamika perkembangan daerah dan nasional. ${ }^{1}$

1 https://dispenda.kutaikartanegarakab.go.id, Diakses Pada Tanggal 26 Mei 2018, Pukul 10.15
Kabupaten Kutai Kartanegara sebagai daerah otonom telah memiliki dokumen perencanaan pembangunan daerah sebagai satu kesatuan yang tidak terpisahkan dari sistem perencanaan pembangunan Provinsi dan Nasional. Pelaksanaan pembangunan Kutai Kartanegara sejak tahun 2011 berpedoman kepada Rencana Pembangunan Jangka Menengah Daerah (RPJMD) Kabupaten Kutai Kartanegara Tahun 2011-2015 yang ditetapkan dengan Peraturan Daerah Nomor 27 Tahun 2010 tentang RPJMD Kabupaten Kutai Kartanegara Tahun 2011-2015. Dalam perjalanan pembangunan jangka menengah yang menginjak tahun ke-3, dilakukan evaluasi terhadap pelaksanaan RPJMD. Berdasarkan hasil evaluasi tersebut, maka dipandang perlu untuk 
melakukan perubahan RPJMD Kabupaten Kutai Kartanegara Tahun 2011-2015. ${ }^{2}$

Berdasarkan Peraturan Bupati Kutai Kartanegara Nomor 40 Tahun 2016 tersebut, kedudukan Badan Pendapatan Daerah merupakan unsur penunjang urusan pemerintahan pemerintah daerah dibidang pendapatan daerah yang berkedudukan di bawah dan bertanggung jawab kepada Bupati, dipimpin oleh Kepala Badan dan bertanggungjawab kepada Bupati melalui Sekretaris Daerah. Sedangkan tugas pokok Badan Pendapatan Daerah yaitu melaksanakan tugas membantu Bupati dalam melaksanakan fungsi penunjang urusan pemerintahan yang menjadi kewenangan daerah di bidang pendapatan daerah. Untuk melaksanakan tugas pokok tersebut, Badan Pendapatan Daerah Kabupaten Kutai Kartanegara mempuyai fungsi:

(1) Penyusunan kebijakan teknis di bidang pendapatan daerah;

(2) Pelaksanaan tugas dukungan teknis di bidang pendapatan daerah;

(3) Pemantauan, evaluasi, dan pelaporan pelaksanaan tugas dukungan teknis di bidang pendapatan daerah;

(4) Pembinaan teknis penyelenggaraan fungsi-fungsi penunjang urusan pemerintahan daerah di bidang pendapatan daerah; dan

(5) Pelaksanaan fungsi lain yang diberikan oleh Bupati sesuai tugas dan fungsinya. ${ }^{3}$

Negara Republik Indonesia sebagai Negara kesatuan, saat ini sedang menerapkan azas desentralisasi dalam penyelenggaraan pemerintah. Desentralisasi merupakan pemberian kesempatan dan keleluasaan kepada daerah untuk menyelenggarakan Otonomi Daerah. Melalui otonomi diharapkan daerah akan lebih mandiri dalam menentukan kegiatannya untuk memajukan daerah. Agar daerah dapat menjalankan kewajiban dengan sebaik-baiknya, perlu sumber keuangan daerah. Semakin besar keuangan

\footnotetext{
${ }^{2}$ Ibid.

3 Dokumen Rencana Strategis (RENSTRA) Badan Pendapatan Daerah Kabupaten Kutai Kartanegara Tahun 2016-2021, hal. 7.
}

daerah, maka akan semakin besar pula kontribusinya terhadap penyelengaraan usaha-usahanya dalam bidang keamanan, ketertiban umum, sosial, kebudayaan, kesejahteraan, serta pelayanan umum kepada masyarakat.

Undang-Undang Nomor 23 Tahun 2014 Tentang Pemerintah Daerah dalam Pasal 285 menyebutkan tentang sumbersumber Pendapatan Daerah meliputi :

(1) Sumber Pendapatan Daerah terdiri atas:

a. Pendapatan asli Daerah meliputi:

1. Pajak daerah;

2. Retribusi daerah;

3. Hasil pengelolaan kekayaan Daerah yang dipisahkan; dan

4. Lain-lain pendapatan asli Daerah yang sah;

b. Pendapatan transfer; dan

c. Lain-lain pendapatan Daerah yang sah.

(2) Pendapatan transfer sebagaimana dimaksud pada ayat (1) huruf b meliputi:

a. Transfer Pemerintah Pusat terdiri atas:

1. Dana perimbangan;

2. Dana otonomi khusus;

3. Dana keistimewaan; dan

4. Dana Desa.

b. Transfer antar-Daerah terdiri atas:

1. Pendapatan bagi hasil; dan

2. Bantuan keuangan.

Semakin besarnya peranan Pendapatan Asli Daerah (PAD) berarti semakin sedikit ketergantungan daerah terhadap bantuan pusat, Pendapatan Asli Daerah (PAD) digunakan untuk membiayai pengeluaran daerah seperti : pengeluaran rutin dan pengeluaran pembangunan. Dari hasil penerimaan pajak sarang burung walet oleh pemerintah digunakan untuk membiayai keperluaan daerah, baik dari segi pembangunan, keamanan, ketertiban lingkungan, dan lain-lain yang berkaitan dengan daerah itu sendiri. Supaya perkembangan daerah menjadi maju, dengan ini daerah harus memiliki 
keunggulan yang dapat dihandalkan. ${ }^{4}$ Salah satu Pendapatan Asli Daerah (PAD) diharapkan menjadi salah satu sumber pembiayaan penyelengaraan pemerintah dan pembangunan daerah untuk meningkatkan dan meratakan kesejahteraan masyarakat adalah dari Pajak Daerah. Pajak daerah telah menjadi sumber penerimaan yang dapat di handalkan bagi daerah.

Dalam Peraturan Daerah Kabupaten Kutai Kartanegara Nomor 2 Tahun 2011 Tentang Pajak Daerah Pasal 1 Pajak Sarang Burung Walet adalah pajak atas kegiatan pengambilan dan/atau pengusahaan sarang burung walet. Dalam meningkatkan Pendapatan Asli Daerah Kabupaten Kutai Kartanegara Pajak Sarang Burung Walet juga berperan penting. Mengingat banyak terdapatnya rumah sarang burung walet yang disediakan oleh pengusaha burung yang dalam hal ini memiliki potensi. Sarang Burung Walet bertujuan untuk menjaga dan melindungi kelestarian sarang burung walet baik dihabitat alami maupun dihabitat buatan dari bahaya kepunahan, serta untuk meningkatkan produksi dalam upaya pemanfaatan untuk kesejahteraan rakyat. Pajak sarang burung walet juga menjadi handalan Pemerintah Daerah memberikan kontribusinya untuk Meningkat Pendapatan Asli daerah (PAD) mengingat terdapat rumah-rumah pengusahaan Sarang burung walet oleh pengusaha yang di jadikan sebagai Wajib Pajak daerah. ${ }^{5}$

\section{B. Permasalahan}

Berdasar pada latar belakang tersebut diatas, maka permasalahan yang dibahas dalam penelitian adalah :

1. Bagaimana peran Badan Pendapatan Daerah Kabupaten Kutai Kartanegara dalam penyelenggaraan pungutan dan melaksanakan pengawasan terhadap pemilik sarang burung walet dalam melaksanakan kewenangannya membayar pajak untuk meningkatkan pendapatan asli daerah?
2. Bagaimana perhitungan tarif pajak sarang burung walet yang ditetapkan sebesar $10 \%$ berdasarkan Peraturan Daerah Kabupaten Kutai Kartanegara Nomor 2 Tahun 2011 tentang Pajak Daerah?

\section{Tujuan dan Manfaat Penelitian}

Adapun yang menjadi tujuan dalam penelitian ini yaitu untuk mengetahui peran Badan Pendapatan Daerah Kabupaten Kutai Kartanegara dalam melakukan penyelenggaraan pungutan dan melaksanakan pengawasan terhadap pemilik sarang burung walet dalam melaksanakan kewenangannya membayar pajak untuk meningkatkan pendapatan asli daerah. Dan untuk Mengetahui perhitungan tarif pajak sarang burung walet yang ditetapkan sebesar $10 \%$ berdasarkan Peraturan Daerah Kabupaten Kutai Kartanegara Nomor 2 Tahun 2011 tentang Pajak Daerah.

Adapun manfaat dari penelitian ini adalah Menjadi salah satu bahan evaluasi Badan Pendapatan Daerah Kabupaten Kutai Kartanegara dalam Meningkatkan Pendapatan Asli Daerah Kabupaten Kutai Kartanegara dan memberikan pemahaman kepada Pengusaha Sarang Burung Walet dalam hal perhitungan pajak agar pengusaha sarang burung walet termotivasi untuk taat dalam melakukan pembayaran pajak sarang burung walet.

\section{METODE PENELITIAN}

Dalam penelitian ini menggunakan metode penelitian Yuridis Normatif atau Metode Penelitian Kepustakaan yaitu motode yang dilakukan dengan cara yang dipergunakan dalam penelitian hukum yang dilakukan dengan cara meneliti bahan pustaka yang ada. Sehingga adapun datadata yang digunakan dalam penelitian ini meliputi :

\footnotetext{
${ }^{4}$ Marohot P. Siahaan, Pajak dan Retribusi Daerah, PT. Rajagrapindo Persada, 2016. Hal. 1

5 Darwin, Pajak Daerah dan Retribusi Daerah, Mitra Wacana Media, 2010, hal.180.
} 


\section{a. Bahan Hukum Primer}

Bahan hukum primer terdiri atas peraturan perundang-undangan yurisprudensi, atau putusan pengadilan. Bahan hukum primer adalah bahan hukum yang bersifat otoritatif yang artinya mempunyai otoritas. Bahan hukum primer yang digunakan dalam penelitian ini yaitu Undang-Undang Nomor 17 Tahun 2003 tentang Keuangan Negara. Undang-Undang Republik Indonesia Nomor 33 Tahun 2004 tentang Perimbangan Keuangan Pusat dan Daerah. Undang-Undang Nomor 16 Tahun 2009 tentang Tata Cara Perpajakan. Undang-Undang Nomor 28 Tahun 2009 tentang Pajak Daerah dan Retribusi Daerah. Undang-Undang Republik Indonesia Nomor 23 Tahun 2014 tentang Pemerintah Daerah. Peraturan Pemerintah Republik Indonesia Nomor 58 Tahun 2005 tentang Pengelolaan Keuangan Daerah. Peraturan Daerah Kabupaten Kutai Kartanegara Nomor 2 Tahun 2011 tentang Pajak Daerah. Peraturan Bupati Kutai Kartanegara Nomor 79 Tahun 2012 tentang Uraian Tugas Pejabat Struktural Pada Dinas Pendapatan Daerah Kabupaten Kutai Kartanegara.

\section{b. Bahan Hukum Sekunder}

Bahan hukum sekunder adalah bahan hukum yang dapat memberikan penjelasan terhadap bahan hukum primer. Bahan hukum sekunder adalah:

1. Buku-buku ilmiah yang terkait

a. Auditing (Dasar-dasar Audit Laporan Keuangan)

b. Akuntansi Sektor Publik: Suatu Pengantar

c. Pajak Daerah dan Retribusi Daerah

d. Metode Penulisan Karya Ilmiah

e. Konsep Dasar Perpajakan

f. Perencanaan Pajak

g. Perpajakan Edisi Revisi

h. Pajak dan Retribusi Daerah

i. Hukum Administrasi Negara

j. Ekonomi Otonomi Daerah

k. Prosedur Penelitian Suatu Pendekatan Praktik.
2. Hasil penelitian

a. Perbaikan Keuangan Negara Dalam Era Reformasi;

b. Evaluasi Kinerja Pendapatan Asli Daerah dan Kemampuan Keuangan Daerah Kabupaten/Kota di Provinsi Lampung;

c. Pengaruh Pendapatan Asli Daerah (PAD) Terhadap Pertumbuhan Ekonomi Provinsi Lampung Menurut Persfektif Ekonomi Islam

d. Analisis Kinerja Pengelolaan Keuangan Daerah Pada Era Otonomi Daeah di Kabupaten Sukoharjo

\section{c. Bahan Hukum Tersier}

Bahan-bahan yang memberikan petunjuk maupun penjelasan terhadap bahan hukum primer dan bahan hukum sekunder seperti Kamus Hukum dan Kamus Besar Bahasa Indonesia dan lain sebagainya.

Teknik Pengumpan Data yang digunakan dalam Penelitian ini dengan cara melakukan Penelitian Kepustakaan dengan melihat sumber dalam media dan melakukan wawancara secara langusng kepada Narasumber terkait dengan Judul Penelitian.

Analisis Data Dalam Penelitian ini analisis data yang dilakukan Metode analisis data yang dilakukan adalah dengan metode kualitatif dengan penarikan kesimpulan secara deduktif. ${ }^{6}$ Metode penarikan kesimpulan pada dasarnya ada dua, yaitu metode penarikan kesimpulan secara deduktif dan induktif. Metode penarikan kesimpulan secara deduktif adalah suatu proposisi umum yang kebenarannya telah diketahui dan berakhir pada suatu kesimpulan (pengetahuan baru) yang bersifat lebih khusus. Metode penarikan kesimpulan secara induktif adalah proses berawal dari proposisiproposisi khusus (sebagai hasil pengamatan) dan berakhir pada kesimpulan (pengetahuan baru) berupa asas umum.

6 Soerjono Soekanto dan Sri Mamudji, Penelitian Hukum Normatif Suatu Tinjauan Singkat, PT. Raja Grafindo Persada, 2011, hal. 69 


\section{HASIL DAN PEMBAHASAN}

A. Peran Badan Pendapatan Daerah Kabupaten Kutai Kartanegara Dalam Penyelenggaraan Pungutan dan Melaksanakan Pengawasan Terhadap Pemilik Sarang Burung Walet Dalam Melaksanakan Kewenangannya Membayar Pajak Untuk Meningkatkan Pendapatan Asli Daerah.

Peran Badan Pendapatan Daerah Kabupaten Kutai Kartanegara didalam penyelenggaraan pungutan terhadap pemilik sarang burung walet adalah:

1. Memberikan sosialisasi kepada pengusaha sarang burung walet untuk selalu membayar pajak,

2. Mendaftarkan pengusaha sebagai wajib pajak,

3. Badan Pendapatan Daerah Kabupaten Kutai Kartanegara memberikan Nomor Pokok Wajib Pajak Daerah (NPWPD) kepada pengusaha atau wajib pajak,

4. Badan Pendapatan Daerah Menunggu Wajib Pajak untuk melaporkan berapa pendapatan sarang burung walet dan berapa pajak yang ingin diberikan.

Peranan Badan Pendapatan Daerah Kabupaten Kutai Kartanegara sebagai salah satu cara agar pengusaha sarang burung walet sadar bahwa mereka memiliki tanggung jawab mengenai pembayaran pajak yang sudah diatur mulai dari UndangUndang, Peraturan Daerah, hingga Peraturan Bupati. Peraturan Daerah yang menjadi acuan yaitu Peraturan Daerah Kabupaten Kutai Kartanegara Nomor 2 Tahun 2011 Tentang Pajak daerah dan kemudian turun pada Peraturan Bupati Nomor 45 Tahun 2011 Tentang Pedoman Teknis Pelaksanaan Pemungutan Pajak Sarang Burung Walet.

Sistem pemungutan yang dilakukan oleh Badan Pendapatan Daerah Kabupaten Kutai Kartanegara yaitu Self Assessment System, dimana semua diserahkan kepada wajib pajak. Mulai dari melakukan pelaporan kepada Badan pendapatan Daerah Kabupaten Kutai Kartanegara, melakukan perhitungan untuk melakukan pembayaran pajak hingga menyetor pajak. Badan Pendapatan Daerah Kabupaten Kutai Kartanegara hanya membantu pengusaha mendaftarkan diri sebagai Wajib Pajak, pemberian NPWP, dan penjelasan ijin bila pengusaha tidak memiliki ijin sarang burung walet. Hal ini juga seusai dengan Peraturan Daerah Kabupaten Kutai Kartanegara Nomor 2 Tahun 2011 Tentang Pajak Daerah pada Pasal 89 yang menyatakan bahwa dari Sembilan jenis pajak yang dibayarkan sendiri oleh wajib pajak, salah satunya adalah pajak sarang burung walet.

Pemungutan pajak tidak serta merta dilakukan. Pengusaha sarang burung walet harus terdaftar terlebih dahulu sebagai Wajib Pajak. Hal tersebut sesuai dengan Peraturan Bupati Kabupaten Kutai Kartanegara Nomor 45 Tahun 2011 Tentang Pedoman Teknis Pelaksanaan Pemungutan Pajak Sarang Burung Walet, Pasal 6 Ayat 1 menyatakan bahwa subyek pajak harus mendaftarkan diri sebagai wajib pajak dengan mengisi formulir SPTPD yang disediakan oleh Badan Pendapatan Daerah Kabupaten Kutai Kartanegara. Dalam SPTPD tersebut pengusaha harus mengisi Nama dan alamat, letak lokasi, nomor formulirm, jenis usaha/produksi, data subyek dan obyek pajak lainnya. Kemudian pada ayat 2 disebutkan hawa formulir pendftaran tersebut harus diisi secara jelas, lengkap dan benar dan harus ditandatangani subyek pajak atau kuasanya. hal ini dilakukan untuk mempermudah pengusaha terdaftar sebagai wajib pajak. Bila penyelenggaraan pungutan pajak sarang burung walet bercermin pada Undang-Undang Republik Indonesia Nomor 28 Tahun 2009 Tentang Pajak Daerah Dan Retribusi Daerah ada atau tidak adanya ijin usaha sarang burung walet tim penyelenggara pungutan pajak sarang burung walet tetap wajib menerima pajak yang diberikan oleh wajib pajak. Tetapi tim penyelenggara pungutan pajak sarang burung walet berbenturan dengan apatur penegak hukum yang tidak mengijinkan melakukan pemungutan pajak yang tidak memiliki ijin dengan alasan melegalkan yang illegal. Dalam Undang-Undang tersebut berbunyi ketika dia (pengusaha) 
sudah jatuh sebagai objek, maka sudah wajib atau berhak dipungut pajaknya. Sejauh wajib pajak ingin menyetor kepada Badan Pendapatan Daerah Kabupaten Kutai Kartanegara, tim penyelenggara pungutan pajak tetap menerima pajak yang diberikan tanpa melihat atau menanyakan masalah ijin tersebut. Tetapi bila wajib pajak ataupun pengusaha sarang burung walet tidak mau menyetor kepada tim penyelenggara pungutan, tidak akan terjadi paksaan karena semua murni atas kemauan dari pengusaha dan wajib pajak.

Penyetoran hasil pajak sarang burung walet sudah ditentukan dalam peraturan daerah dan peraturan bupati. Bila dalam penentuan tersebut pengusaha sarang burung walet belum melakukan penyetoran maka akan dikenakan sanksi sebesar $2 \%$ sesuai dengan Peraturan Bupati Kutai Kartanegara Nomor 45 Tahun 2011 Tentang Pedoman Teknis Pelaksanaan Pemungutan Pajak Sarang Burung Walet sesuai dalam Pasal 14 ayat 4 poin a yang menyatakan angsuran pembayaran dilakukan secara teratur dan berturut-turut maksimal 4 kali selama-lamanya 1 tahun sejak tanggal persetujuan Bupati, dengan dikenakan sanksi bunga $2 \%$ sebulan dari jumlah pajak yang belum atau kurang dibayar.

Kelemahan dari Peraturan Daerah Kabupaten Kutai Kartanegara Nomor 2 Tahun 2011 Tentang Pajak Daerah dan Peraturan Bupati Kutai Kartanegara Nomor 45 Tahun 2011 Tentang Pedoman Teknis Pelaksanaan Pemungutan Pajak Sarang Burung Walet disini ialah tidak adanya sanksi bagi pengusaha sarang burung walet yang tidak terdaftar sebagai wajib pajak. Data yang dimiliki oleh Badan Pendapatan Daerah Kabupaten Kutai Kartanegara adalah hanya data pengusaha yang terdaftar sebagai wajib pajak. Dari hasil daftar wajib pajak sarang burung walet periode 1 januari 2016 sampai dengan 30 april 2018 yang terdaftar sebagai wajib pajak hanya sebanyak 123 Wajib Pajak. Hal ini tidak sebanding dengan keadaan di lapangan, banyaknya pengusaha sarang burung walet tidak sebanding dengan daftar wajib pajak dimasing-masing kecamatan. Kabupaten Kutai Kartanegara terbagi sebelas kecamatan. Dalam setiap kecamatan hanya puluhan bahkan ada yang hanya belasan yang terdaftar sebagai wajib pajak. Sedangkan bila dilihat dilapangan dalam satu kecamatan ada raturan bangunan sarang burung walet. Mulai dari bangunan sarang burung walet yang berdiri sendiri ataupun bangunan sarang burung walet yang menjadi satu tempat dengan tempat tinggal pemiliknya. Hal ini terjadi karena kurangnya kesadaran pengusaha sarang burung walet untuk menjadi wajib pajak dan kurangnya monitoring tim terpadu kepada pengusaha sarang burung walet di wilayah kerjanya sendiri.

$$
\text { Badan Pendapatan Daerah }
$$

Kabupaten Kutai Kartanegara pada saat ini hanya bisa berharap pembayaran pajak dapat berjalan baik pada 123 wajib pajak. Tetapi pada kenyataannya setahun setelah terdaftar sebagai wajib pajak, yang melakukan pembayaran pajak hanya 4 orang wajib pajak saja. Dan hal ini jauh dari target dan harapan. Pelaksanaan pungutan pajak sarang burung walet yang tidak tecapai atau tidak memenuhi target terjadi mulai dari tahun 2015 hingga saat ini. Target yang ditetapkan Badan Pendapatan Daerah Kabupaten Kutai Kartanegara tidak pernah terpenuhi, bahkan untuk mencapai $10 \%$ dari target saja tidak tercapai. Dari trend pendapatan asli daerah yang ada. Pada tahun 2015 target yang ditentukan sebesar Rp. 10.000.000 dan yang teralisasi adalah Rp. 0. Untuk tahun 2016 target yang ditentukan adalah Rp. 11.000.000 dan realisasinya adalah Rp. 600.000, pencapaian sebesar $5,45 \%$ dari taget yang ditentukan. Ditahun 2017 target yang ditentukan adalah Rp. 60.000.000 dan yang terealisasi adalah Rp. 1.760.2502, pencapaian sebesar 2,93\%. Pada tahun 2018 target sebesar Rp. 50.990.000 dan yang terealisasi sejuah ini adalah Rp. 530.000, pencapaian sebesar $1,04 \%$.

Salah satu pengusaha sarang burung walet yang berada di Kecamatan Tenggarong beralasan karena kesibukan mereka, maka tidak sempat atau tidak memiliki waktu untuk mendaftarkan dirinya sebagai wajib pajak. Maka dari itu dari mulai tahun 2013 sarang burung walet berproduksi, pengusaha tidak pernah 
membayar pajaknya. Dan pengusaha pun belum pernah dikunjungi oleh tim terpadu mengenai pendataan dan pendaftaran pajak. Pengusaha sarang burung walet merasa terbebani bila terdaftar sebagai wajib pajak. Karena merasa memiliki tanggungan tambahan. Maka dari itu mereka merasa biasa saja bila tidak serdaftar sebagai wajib pajak dan tidak membayar pajak.

Berbeda dengan yang disampaikan dari pihak Badan Pendapatan Daerah Kabupaten Kutai Kartanegara yang selama ini melakukan pendataan diseluruh Kabupaten Kutai Kartanegara melalui UPT yang terbagi dalam sebelas UPT tersebut. Ada hal lain yang menjadi kendala tim penyelenggara pungutan pajak Badan Pendapatan Daerah Kabupaten Kutai Kartanegara dalam melalukan pemungutan pajak yaitu tingkat kesadaran wajib pajak masih rendah. Mereka selalu beralasan bahwa usaha yang mereka bangun selama ini adalah usaha sendiri. Pemerintah tidak pernah berperan didalamnya. Peran pemerintah yang mereka harapkan selama ini adalah seperti pembinaan terhadap pengusaha dalam bentuk pelatihan atau bimbingan tekhnis untuk mengelola sarang burung walet agar sarang burung walet yang mereka miliki selalu berproduksi tanpa mengenal hambatan. Sementara tim penyelenggara pungutan Badan Pendapatan Daerah Kabupaten Kutai Kartanegara sudah memberikan pemahaman bahwa hasil dari pungutan pajak tidak bisa dirasakan secara langsung tetapi secara tidak langsung seperti dalam bentuk fasilitas jalan kemudian bangunan sarana pendidikan, sarana kesehatan yang dari semua itu berasal dari pungutan pajak. Tapi berbeda dengan keinginan pengusaha yang berharap hasil pungutannya dapat mereka rasakan secara langsung.

Selain itu pula masalah lain ialah harapan dari pengusaha sarang burung walet disini adalah pungutan sarang burung walet dapat dirasakan secara langsung yaitu dengan cara membantu atau menjembatani memberikan pinjaman kepada bank untuk dapat mengembangkan usahanya. Hal ini yang menjadi alasan pengusaha sarang burung walet tidak ingin membayar pajak karena masalah Bank tidak memberikan peminjaman permodalan kepada pengusaha sarang burung walet bila ingin membuka usaha sarang burung walet. Dengan alasan burung walet tidak bisa menjadi salah satu hewan yang bisa diakui kepemilikannya.

Dalam Peraturan daerah Nomor 2 Tahun 2011 Tentang Pajak Daerah, Pasal 3 ayat 1disebutkan bahwa tujuan dari pajak daerah itu sendiri ialah untuk penyelenggaraan otonom daerah dengan menempatkan diri pada pembebanan pajak daerah. Dalam ayat 2 menyatakan sebagai pedoman, arahan, panduan dalam rangka pemungutan pajak daerah yang meliputi pendataan, penetapan dan penagihan. Hal terpenting lainnya disini disebutkan pada ayat 3 bahwa pajak daerah menjadi salah satu sumber pendapatan daerah. Maka bila dilaksanakan dengan baiik, pendapatan asli daerah pun akan meningkat.

Banyaknya permasalahan atau kendala-kendala Badan Pendapatan Daerah Kabupaten Kutai Kartanegara dalam menyelenggarakan pungutan pajak sarang burung walet, maka dari itu tim penyelenggara pungutan pajak sarang burung walet Badan Pendapatan Daerah Kabupaten Kutai Kartanegara diawal tahun 2018 membuat program baru yang bernama Jemput Bola Pajak Sarang Burung Walet (Jebol Pak Sabu). Kemunculan program baru ini diharapkan dapat mengoptimalisasi penyelenggaraan pungutan pajak di Kabupaten Kutai Kartanegara. Program jemput bola pajak sarang burung walet ini baru dilaksanakan pada Desa Perian Kecamatan Muara Muntai. Pelaksanaan pertama pada Desa Perian bukan tanpa alasan, melainkan salah satu dari Unit Pelaksana Teknis Pajak Daerah menginformasikan kepada Badan Pendapatan Daerah Kabupaten Kutai Kartanegara Bahwa di UPT yang berkedudukan di Kecamatan Muara Muntai siap membayar pajak sarang burung walet yang bila dihitung-hitung memiliki potensi sebesar \pm Rp. 2.000.000.000. Kemudian pada saat Badan Pendapatan Daerah Kabupaten Kutai Kartanegara menurunkan tim ke lapangan untuk melakukan sosialisasi dan pelayanan pembayaran pajak sarang burung walet dengan melibatkan Bank BPD Kaltim, Satuan Polisi Pamong 
Praja, dan Badan Pelayanan Perizinan Terpadu (BP2T) Kabupaten Kutai Kartanegara dengan harapan dapat terintegrasi dengan baik. Dan pada saat sesampainya ditempat tujuan yaitu Desa Perian, semua jauh dari harapan. Karena tim dari Badan Pendapatan Daerah Kabupaten Kutai Kartanegara hanya bisa mendaftarkan pengusaha sebagai Wajib Pajak dan sementara pembayaran pajak belum bisa terealisasikan.

Badan Pendapatan Kabupaten Kutai Kartanegara mempunyai prinsip tidak akan memeras atau memaksa masyarakat untuk membayar pajak karena pemahaman dari Badan Pendapatan Daerah Kabupaten Kutai Kartanegara yaitu walaupun Pendapatan Asli Daerah (PAD) ditingkatkan berapa puluh persen tidak akan signifikan dalam menutupi pembiayaan pembangunan, dan kalaupun masyarakat dipaksa untuk membayar pajak semua, maka tidak akan mempengaruhi peningkatan pendapatan asli daerah begitu besar dalam hal pembangunan. Tetap saja daerah Kabupaten Kutai Kartanegara selalu berharap dana yang diberikan dari pusat. Sebenarnya dalam Peraturan Bupati Kabupaten Kutai Kartanegara Nomor 45 Tahun 2011 Tentang Pedoman Teknis Pelaksanaan Pemungutan Pajak Sarang Burung Walet, Pasal 23 ayat 2 disebutkan bahwa Dispenda wajib memberikan arahan kepada pengusahaan dan/atau pengambilan sarang burung walet yang tidak berijin untuk dapat memperoses perijinan. Maka disini sifatnya tetap membina dengan cara memberikan arahan sampai akhirnya pengusaha mendapatkan ijinnya.

Trend Pendapatan Asli Daerah pada tahun 2015 hingga 2018 bisa dikatakan stabil dari target yang ada, walau dalam 3 tahun terakhir terjadi penurunan tetapi penurunan tersebut tidak begitu berpengaruh. Untuk pendapatan asli daerah pada tahun 2015 pajak daerah terealisasi sebanyak $106.05 \%$ dari target yang ditentukan. Di tahun 2016 terjadi penurunan yaitu hanya terealisasi $75.23 \%$. Di tahun 2017 pajak daerah terjadi peningkatan kembali yaitu terealisasi sebanyak 94.92\%. Pada tahun 2018 ini pajak daerah baru terealisasi sebesar
44.14\% yang dihitung dari bulan januari hingga bulan juni.

Dalam Peraturan Daerah Kabupaten Kutai Kartanegara Nomor 2 Tahun 2011 Tentang Pajak Daerah, pada Pasal 62 ayat 1 disebutkan bahawa yang dimaksud dengan objek pajak sarang burung walet adalah pengambilan dan/atau pengusahaan sarang burung walet, dan pada ayat 2 disebutkan bahwa pengambilan sarang burung walet yang telah dikenakan Penerimaan Negara Bukan Pajak tidak termasuk dalam objek pajak sarang burung walet. Pemahaman lainnya yang tidak diketahui masyarakat atau pengusaha sarang burung walet yaitu mengenai pajak sarang burung walet yang berbeda jenis pajaknya dengan jenis pajak yang lain. Jenis pajak lain yang dimaksud disini adalah Penerimaan Negara Bukan Pajak (PNBP). Seperti halnya pada saat pengepul sarang burung walet melakukan pengiriman sarang burung walet yang belum dibayar pajak daerahnya, maka pada saat dibandara pengepul akan dikenakan pajak sebesar $10 \%$. Hal tersebut membuat kerugian terhadap daerah karena PNBP langsung diberikan kepada pusat dan tidak dibagi ke daerah.

Badan Pendapatan Daerah

Kabupaten Kutai Kartanegara tidak melaksanakan pengawasan terhadap pemilik sarang burung walet dalam melaksanakan kewenangannya membayar pajak. Hal tersebut terjadi karena mereka mengaanggap bukan tugas dan fungsi dari Badan Pendapatan Daerah Kabupaten Kutai Kartanegara. Yang dilakukan hanya sebatas pendataan dan pendaftaran terhadap pengusaha sarang burung walet. Dan yang layak melakukan pengawasan adalah Satuan Polisi Pamong Praja (SATPOL PP).

Keadaan tersebut tidak sesuai dengan

Peraturan Bupati Kabupaten Kutai Kartanegara Nomor 45 Tahun 2011 Tentang Pedoman Teknis Pelaksanaan Pemungutan Pajak Sarang Burung Walet. Dalam pasal 23 sudah jelas disebutkan bahwa pengawasan merupakan tanggung jawab dari Badan Pendapatan Daerah Kabupaten Kutai Kartanegara, kalaupun Badan Pendapatan Daerah Kabupaten Kutai Kartanegara menganggap pengawasan lebih baik ditangani oleh SATPOL PP 
seharusnya Badan Pendapatan Daerah Kabupaten Kutai Kartanegara melakukan koordinasi kepada SATPOL PP untuk melakukan pengawasan. Tetapi hal tersebut belum bisa terealisasi sampai saat ini karena berbagai macam kendala seperti anggaran yang tidak memungkinkan dan waktu yang tidak cukup, karena Badan Pendapatan Daerah Kabupaten Kutai Kartanegara tidak berfokus pada pajak sarang burung walet tetapi ada sepuluh jenis pajak lainnya.

Pada saat pengusaha sarang burung walet sudah terdaftar sebagai wajib pajak, seharusnya Badan Pendapatan Daerah Kabupaten Kutai Kartanegara memonitoring, memberikan peringatan kepada wajib pajak untuk melakukan pembayaran pajak. Tetapi sejauh ini Badan Pendapatan Daerah Kabupaten Kutai Kartanegara hanya menunggu wajib pajak untuk membayar pajaknya. Maka dari itu pembayaran pajak tidak bisa terealisasikan.

Hal lain yang membuat pengawasan tidak berjalan yaitu karena lokasi bangunan sarang burung walet yang berbeda dengan lokasi tempat tinggal pemilik sarang burung walet. Kalaupun dilakukan pengecekan dilapangan hanya dapat bertemu dengan penjaga dari bangunan sarang busrung walet tersebut, tidak dapat bertemu langsung dengan pemilik sarang burung walet. Dan tim terpadu tidak bisa melakukan monitoring lapangan karena keterbatasan waktu dan dana.

$$
\text { Badan Pendapatan Daerah }
$$

Kabupaten Kutai Kartanegara melakukan pengawasan dengan cara memberikan himbauan untuk taat akan pembayaran pajak. Tetapi pada saat penulis meminta bukti laporan surat himbauan yang diberikan kepada wajib pajak atau pengusaha sarang burung walet laporan tersebut tidak ada dan pengawasan tersebut tidak benar-benar terjadi.

Menurut pendapat penulis peran Badan Pendapatan Daerah Kabupaten Kutai Kartanegara dalam penyelenggaraan pungutan dan melaksanakan pengawasan terhadap pemilik sarang burung walet dalam melaksanakan kewenangannya membayar pajak untuk meningkatkan pendapatan asli daerah masih belum maksimal, Seharusnya dalam penyelenggaraan pungutan juga harus dilakukan pengawasan, agar dapat mengevaluasi penyelenggaraan pungutan tersebut agar semua pengusaha sarang burung walet dapat dilakukan pendataan kemudian terdaftar menjadi wajib pajak dan yang sudah terdaftar menjadi wajib pajak dapat taat akan kewajibannya untuk membayar pajak. Dan pendapatan asli daerah yang bersumber dari pajak sarang burung walet dalam hal peningkatan pendapatan tidak signifikan dari tahun 2015-2018.

\section{B. Perhitungan Tarif Pajak Sarang Burung Walet Yang Di Tetapkan Sebesar $\quad 10 \% \quad$ Berdasarkan Peraturan Daerah Kabupaten Kutai Kartanegara Nomor 2 Tahun 2011 tentang Pajak Daerah.}

Perhitungan tarif pajak sarang burung walet ditetapkan untuk memudahkan para wajib pajak menghitung besaran pajak yang akan disetor kepada Badan Pendapatan Daerah Kabupaten Kutai Kartanegara. Perhitungan pajak sebesar 10\% diperuntukan untuk kedua jenis sarang burung walet yaitu sarang burung walet alam dan sarang burung walet menggunakan habitat buatan. Hal ini pun tertera dalam Peraturan Bupati Kabupaten Kutai Kartanegara Nomor 45 Tahun 2011 Tentang Pedoman Teknis Pelaksanan Pemungutan Pajak Sarang Burung Walet dalam Pasal 2 ayat 1 menyatakan yang dimaksud dengan objek pajak sarang burung walet adalah kegiatan pengambilan dan/atau pengusahaan sarang burung walet yang berada di habitat alami burung walet dan habitat buatan burung walet.

Perhitungan pajak $10 \%$ banyak tidak diketahui oleh semua pengusaha sarang burung walet karena pengusaha sarang burung tidak terdaftar sebagai wajib pajak, terlebih pengusaha sarang burung walet yang baru memulai usahanya tidak mendapatkan sosialisasi dari Badan Pendapatan Daerah Kabupaten Kutai Kartanegara. Dan adapula pengusaha yang sudah menjadi wajib pajak dan memahami bagaimana perhitungan pembayaran pajak 
sebesar $10 \%$ tetapi tetap tidak ingin membayar pajaknya.

Bagi pengusaha sarang burung walet yang sudah menjadi wajib pajak pasti mengetahui apa saja yang harus dilakukan untuk membayar pajak. Bila wajib pajak ingin membayar pajaknya maka wajib pajak akan mendapatkan surat keterangan yang berisi NPWPD, nama wajib pajak, alamat usaha sarang burung walet, masa petik yang terdiri dari tanggal dan bulan pemetikan, volume, harga jual dan hasil pemetikan. Kemudian setelah surat keterangan tersebut terisi, wajib pajak menyerahkan kepada tim pelayanan pembayaran pajak di Badan Pendapatan Daerah Kabupaten Kutai Kartanegara dan tim akan menuangkannya lewat SPTDP (Surat Pemberitahuan Pajak Daerah). Hal ini juga sudah ditetapkan sesuai Peraturan Bupati Kabupaten Kutai Kartanegara Nomor 45 Tahun 2011 Tentang Pedoman Teknis Pelaksanaan Pemungutan Pajak Sarang Burung Walet, Pasal 7. Hanya tingkat kesadaran yang masih rendah, yang membuat wajib pajak hanya sekedar mengetahui tanpa menerapkan dengan cara membayar pajak.

Kelemahan dari perhitungan tarif pajak sarang burung walet yang ditetapkan sebesar 10\% berdasarkan Peraturan Daerah Kabupaten Kutai Kartanegara Nomor 2 Tahun 2011 tentang Pajak Daerah yaitu penetapan tarif pajak sebesar 10\% diberikan dengan cara sepihak tanpa mengukur tingkat kemampuan pengusaha sarang burung walet. Dan untuk kelebihan dari Peraturan Daerah Kabupaten Kutai Kartanegara Nomor 2 Tahun 2011 tentang Pajak Daerah yaitu bila ketetapan tarif pajak sebesar $10 \%$ dapat terlaksana maka Pendapatan Asli Daerah khususnya pajak sarang burung walet akan meningkat.

Pemungutan pajak sarang burung walet dihitung dari nilai yang dijual. Misalnya dalam satu bulan ada produksi 2 $\mathrm{kg}$ sarang burung walet. Dari $2 \mathrm{~kg}$ sarang burung walet itu dihitung harga pasarannya. Misalnya pada saat itu harga pasarannya adalah Rp. 20.000.000, maka Rp. 20.000 .000 dikali $2 \mathrm{~kg}$ dikali $10 \%$. Maka hasil dari perkalian itulah yang akan disetor sebagai pajak.
Menurut pendapat penulis perhitungan tarif pajak sarang burung walet yang di tetapkan sebesar 10\% berdasarkan Peraturan Daerah Kabupaten Kutai Kartanegara Nomor 2 Tahun 2011 tentang Pajak Daerah sudah cukup baik namun dalam segi penerapan harus dilakukan sosialisasi kepada pengusaha sarang burung walet. Agar pengusaha sarang burung walet memahami lebih jelas mengenai perhitungan pajak sarang burung walet yang diperuntukan untuk kedua jenis sarang burung walet.

\section{PENUTUP KESIMPULAN DAN SARAN}

Peran Badan Pendapatan
Kabupaten Kutai Kartanegara
penyelenggaraan $\begin{array}{r}\text { dalam } \\ \text { pungutan }\end{array}$
melaksanakan pengawasan terhadap
pemilik sarang burung walet dalam
melaksanakan kewenangannya membayar
pajak untuk meningkatkan pendapatan asli
daerah masih belum maksimal. Dalam
penyelenggaraan pungutan juga harus
dilakukan pengawasan, agar dapat
mengevaluasi penyelenggaraan pungutan tersebut agar semua pengusaha sarang burung walet dapat dilakukan pendataan kemudian terdaftar menjadi wajib pajak dan yang sudah terdaftar menjadi wajib pajak dapat taat akan kewajibannya untuk membayar pajak. Dan pendapatan asli daerah yang bersumber dari pajak sarang burung walet dalam hal peningkatan pendapatan tidak signifikan dari tahun 2015-2018.

Perhitungan tarif pajak sarang burung walet yang di tetapkan sebesar $10 \%$ berdasarkan Peraturan Daerah Kabupaten Kutai Kartanegara Nomor 2 Tahun 2011 tentang Pajak Daerah sudah cukup baik namun dalam segi penerapan harus dilakukan sosialisasi kepada pengusaha sarang burung walet. Agar pengusaha sarang burung walet memahami lebih jelas mengenai perhitungan pajak sarang burung walet yang diperuntukan untuk kedua jenis sarang burung walet. 
Adapun saran yang disampaikan dalam penelitian ini sebaiknya Badan Pendapatan Daerah Kabupaten Kutai Kartanegara lebih memaksimalkan kinerjanya dalam melakukaan pendataan dan pendaftaran dan merubah Self Assessment system menjadi Official Assessment System agar dapat membantu wajib pajak menentukan besaran pajak yang akan disetor. Dan meningkatkan pengawasan dan pengendalian teknis pemungutan pajak sarang burung walet.

$$
\text { Badan Pendapatan Daerah }
$$

Kabupaten Kutai Kartanegara perlu melakukan sosialisasi dan melakukan monitoring mengenai perhitungan pajak sarang burung walet kepada pengusaha dan wajib pajak sesuai dengan Peraturan Bupati Kabupaten Kutai Kartanegara Nomor 45 Tahun 2011 Tentang Pedoman Teknis Pelaksanaan Pemungutan Pajak Sarang Burung Walet yang merupakan tanggungjawabnya dan melakukan kerjasama dengan instansi terkait agar pengawasan dan berjalan dengan maksimal.

\section{DAFTAR PUSTAKA}

\section{Buku :}

Abdul Halim, 2015, Auditing (Dasar-dasar Audit Laporan Keuangan), Yogyakarta, Unit Penerbit dan Percetakan STIM YKPN.

Bastian, Indra, 2011, Akuntansi Sektor Publik: Suatu Pengantar, Jakarta, Erlangga.

Darwin, 2010, Pajak Daerah dan Retribusi Daerah, Jakarta, Mitra Wacana Media.

Denial A.R, 2010, Metode Penulisan Karya Ilmiah, Bandung, Universitas PKN Universitas Pendidikan Indonesia.

Diana Sari, 2013, Konsep Dasar Perpajakan, Bandung, PT. Refika Aditama.

Dokumen Rencana Trategis (RENSTRA) Badan Pendapatan Daerah Kabupaten Kutai Kartanegara Tahun 2016-2021.

Erly Suandy, 2011, Perencanaan Pajak, Jakarta, Salemba empat.
Jum Anggraini, 2012, Hukum Administrasi Negara, Yogyakarta, Graha Ilmu.

M. Haddin Muhjad, 2015, Hukum Lingkungan, Jakarta, Genta Publishing.

Mardiasmo, 2013, Perpajakan Edisi Revisi, Yogyakarta, Penerbit Andi.

Marohot, 2016, Pajak dan Retribusi Daerah, Jakarta, PT. Raja grapindo Persada.

Riawan Tjandra, 2014, Hukum Administrasi Negara, Yogyakarta, Grasindo.

Rudy Badrudin, 2011, Ekonomi Otonomi Daerah, Yogyakarta, UPP STIM YKPN.

Soerjono Soekanto dan Sri Mamudji, 2011, Penelitian Hukum Normatif Suatu Tijauan Singkat, Jakarta, PT. Raja Grafindo Persada. 
Suharsimi Arikunto, 2010, Prosedur Penelitian Suatu Pendekatan Praktik, Jakarta, Rinekacipta.

\section{Perundang-undangan :}

Undang-Undang Nomor 17 Tahun 2003 tentang Keuangan Negara.

Undang-Undang Republik Indonesia Nomor 33 Tahun 2004 tentang Perimbangan Keuangan Pusat dan Daerah.

Undang-Undang Nomor 16 Tahun 2009 tentang Tata Cara Perpajakan.

Undang-Undang Nomor 28 Tahun 2009 tentang Pajak Daerah dan Retribusi Daerah.

Undang-Undang Republik Indonesia Nomor 23 Tahun 2014 tentang Pemerintah Daerah.

Peraturan Pemerintah Republik Indonesia Nomor 58 Tahun 2005 tentang Pengelolaan Keuangan Daerah.

Peraturan Daerah Kabupaten Kutai Kartanegara Nomor 2 Tahun 2011 tentang Pajak Daerah.

Peraturan Bupati Kabupaten Kutai Kartanegara Nomor 45 Tahun 2011 Tentang Pedoman Teknis Pelaksanaan Pemungutan Pajak Sarang Burung Walet

Peraturan Bupati Kutai Kartanegara Nomor 79 Tahun 2012 tentang Uraian Tugas Pejabat STruktural Pada Dinas Pendapatan Daerah Kabupaten Kutai Kartanegara.

\section{Artikel / Majalah dan/atau Jurnal :}

Eka Ratnawati, 2011, Perbaikan Keuangan Negara Dalam Era Reformasi, Hasil Penelitian Universitas Atma Jaya, Yogyakarta.

Felisitas Devinta Tania, 2016, Evaluasi Kinerja Pendapatan Asli Daerah dan Kemampuan Keuangan Daerah Kabupaten/Kota di Provinsi Lampung, Universitas Sebelas Maret, Solo.

Nerpi Handayani, 2017, Pengaruh Pendapatan Asli Daerah (PAD) Terhadap Pertumbuhan Ekonomi Provinsi Lampung Menurut
Persfektif Ekonomi Islam, Bandar Lampung, Universitas Islam Negeri Raten Intan.

Safitri, 2013, Analisis Kinerja Pengelolaan Keuangan Daerah Pada Era Otonomi Daeah di Kabupaten Sukoharjo, Surakarta, Universitas Sebelas Maret.

\section{Website :}

https://ejurnal.untag-smd.ac.id https://dispenda.kutaikartanegarakab.go.id 